\title{
Variability and Stability Analysis for Nutritional Traits in the Mini Core Collection of Peanut
}

\author{
Hari D. Upadhyaya,^ Ganapati Mukri, Hajisaheb L. Nadaf, and Sube Singh
}

\begin{abstract}
The nutritional quality of peanut (Arachis hypogaea L.) products depends on the protein content, oil content, and composition of oil. Low genetic variability has been a major bottleneck in genetic enhancement of these nutritional traits in commercial cultivars. The present study was conducted to identify stable genotypes with better nutritional traits and good agronomic performance for use in future breeding programs. The 184 mini core accessions and four control cultivars were evaluated for nutritional traits for two seasons at two locations and for agronomic traits at one location. Significant genotypic and genotype $\times$ environment interactions were observed for all the nutritional and agronomic traits in the entire mini core collection and within each $A$. hypogaea subspecies of fastigiata Waldron and hypogaea. Eighteen accessions with higher nutritional traits such as protein content, oil content, oleic acid, and oleic to linoleic acid ratio with superior agronomic traits were identified and their stability analysis resulted in identification of a high oleic acid content $(>73 \%)$ accession (ICG 2381). On the basis of higher nutritional and agronomic traits 11 subsp. fastigiata and 10 subsp. hypogaea diverse accessions were identified with more than two trait combinations for use in peanut breeding programs for genetic enhancement of nutritional traits.
\end{abstract}

H.D. Upadhyaya and S. Singh, International Crops Research Institute for the Semi-Arid tropics (ICRISAT), Patancheru PO, Hyderabad, Andhra Pradesh 502 324, India; G. Mukri and H.L. Nadaf, Dep. of Genetics \& Plant Breeding, Univ. of Agricultural Sciences, Dharwad, Karnataka 580 005, India. Received 4 May 2011. *Corresponding author (h.upadhyaya@cgiar.org).

Abbreviations: $\sigma^{2}$ g, variance due to genotype; $\sigma^{2}$ ge, genotype $x$ environment interaction; $\sigma^{2} \mathrm{gl}$, genotype $\times$ location interaction; $\sigma^{2} \mathrm{gs}$, genotype $\times$ season interaction; $b_{i}$, linear response; MPLS, modified partial least square; NIR, near-infrared; NIRS, near-infrared spectroscopy; O:L, oleic to linoleic acid ratio; PC, principal component; R, reflectance; $\mathrm{S}^{2} \mathrm{~d}$, nonlinear response; SECV, standard error of cross-validation; UAS, University of Agricultural Sciences; VR, ratio of unexplained variance to total variance.

$\mathrm{P}$ EANUT (Arachis hypogaea L.) is widely grown in more than 100 countries of tropical, subtropical, and warm temperate regions of the globe. This crop is cultivated annually on about 23.95 million ha worldwide with annual production of 36.46 million $t$ in shell and productivity of about $1.52 \mathrm{t} \mathrm{ha}^{-1}$ (FAO, 2009). Peanuts are primarily used for extraction of edible oil in Southeast Asian countries and as a food crop with various confectionery and other manufactured products in European and American countries. In recent years, there has been a major shift toward its use as a food crop rather than a source of edible oil in developing countries, including China and India, where protein from animal sources is not within the reach of majority of the population.

The quality of the edible oil and various food products of peanut depends on the total oil and protein content in seeds and fatty acid composition of the commercially grown cultivars. Most of the cultivars (with exceptions of high oleic mutants and cultivars bred for

Published in Crop Sci. 52:168-178 (2012).

doi: $10.2135 /$ cropsci2011.05.0248

Published online 4 Oct. 2011.

(C) Crop Science Society of America | 5585 Guilford Rd., Madison, WI 53711 USA

All rights reserved. No part of this periodical may be reproduced or transmitted in any form or by any means, electronic or mechanical, including photocopying, recording, or any information storage and retrieval system, without permission in writing from the publisher. Permission for printing and for reprinting the material contained herein has been obtained by the publisher. 
high oleic trait) and germplasm belonging to $A$. hypogaea $\mathrm{L}$. subsp. fastigiata Waldron have almost equal proportions $(40 \%$ each) of oleic acid and linoleic acid while cultivars of $A$. hypogaea L. subsp. hypogaea possess slightly higher (45-60\%) oleic acid compared to linoleic acid (25-30\%). These two fatty acids together with a saturated palmitic acid, constitute the major bulk (>90\%) of fatty acids in peanut. Among these major fatty acids, oleic monounsaturated fatty acid has the dual advantage of enhanced shelf life of the products and health benefits with lower cardiovascular and other related health risks (Frankel, 1991; Carlson, 1995; Fraser et al., 1997). Polyunsaturated fatty acids have a high potential of developing off flavors during storage due to high oxidation. The rate of oxidation of linoleic acid has been reported to be 10 times higher compared to oleic acid (Frankel, 1991; Lands, 1997); therefore, products of higher oleic to linoleic acid ratio (O:L) have a longer shelf life. The research results of Mozingo et al. (2004) showed a significant advantage of high oleic peanuts for extending shelf life of large-seeded, Virginia-type peanuts for either roasted or salted in-shell processing. Gorbet and Knauft (1997) found that products of 'SunOleic 95R', a high oleic runner cultivar, had a much longer shelf life than those from the traditional runner-type peanut cultivars.

Both saturated fatty acids and polyunsaturated fatty acids in high proportions are harmful to health due to their hyper or hypocholesterolemic nature whereas monounsaturated oleic acid has been reported to be neutral (Groff et al., 1996; Grande and Denke, 1990). Oleic acid lowers harmful low-density lipoprotein (LDL) as effectively as linoleic acid but does not affect beneficial high-density lipoprotein (HDL) levels in blood serum (O'Bryne et al., 1997; Kris-Etherton, 2001). Therefore, high oleic peanut cultivars with high oil content for oil extraction and high oleic cultivars with high protein content for peanut products are preferred, but the efforts to breed for such cultivars are lacking especially in developing countries due to insufficient genetic variability for the traits (Norden et al., 1987).

The evaluation and screening of germplasm and wild species collections in the United States have indicated low genetic variability for oil and protein content and fatty acid composition (Hammonds et al., 1997). A total collection of 15,445 accessions representing global germplasm are maintained at ICRISAT in Patancheru, India. When the size of the collection is too large, it becomes unmanageable to evaluate and identify useful germplasm. A very small proportion of the total accessions are being used in peanut breeding programs. Alternatively, after constructing a core collection (1704 accessions) of the world germplasm collection (Upadhyaya et al., 2003), an even smaller mini core collection (184 accessions) was developed using taxonomical, geographical, and morphological descriptors (Upadhyaya et al., 2002). The mini core collection represented variability present in the core collection that represented variability in the entire germplasm collection. Evaluation of the mini core collection has resulted in identification of diverse accessions with drought tolerance (Upadhyaya, 2005), salinity tolerance (Srivastava, 2010), high yield potential, high shelling percentage, $100-$ seed weight $(\mathrm{H}$. Upadhyaya, unpublished data, 2009), and multiple resistance to diseases (Kusuma et al., 2007).

There have been limited attempts to evaluate diverse germplasm for nutritional traits in combination with agronomic performance. Our objective was to identify diverse accessions in the mini core collection with high oil content, protein content, and high oleic acid with high O:L coupled with better agronomic performance for use in breeding enhanced nutritional traits in peanut.

\section{MATERIALS AND METHODS}

The peanut mini core collection, consisting of 184 germplasm accessions selected from 1704 core collection accessions, representing the global germplasm of 14,310 accessions maintained at ICRISAT genebank (Upadhyaya et al., 2002) was utilized in the present investigation. The mini core collection consisted of 37 subsp. fastigiata var. fastigiata, 58 subsp. fastigiata var. vulgaris Harz, two subsp. fastigiata var. peruviana Krapov. \& W. C. Greg., and one subsp. fastigiata var. aequatoriana Krapov. \& W. C. Greg. botanical varieties belonging to subsp. fastigiata and 85 subsp. hypogaea var. hypogaea and one subsp. hypogaea var. hirsuta J. Kohler. The four control cultivars used in the study were M 13, ICGS 76 (both subsp. hypogaea var. hypogaea), ICGS 44 (subsp. fastigiata var. vulgaris), and Gangapuri (subsp. fastigiata var. fastigiata). M 13 (Reddy, 1988) and Gangapuri (Isleib et al., 1994) are cultivars developed by the national research centers whereas ICGS 44 (ICGV 87128 [PI 537112]) (Nigam et al., 1990) and ICGS 76 (ICGV 87141 [PI 546372]) (Nigam et al., 1991) are high-yielding cultivars developed at ICRISAT and released for cultivation in India. These 188 genotypes were evaluated in an $\alpha$ design (four blocks each of 47 plots) with three replications in the 2008 rainy and 2008/2009 post-rainy seasons at ICRISATPatancheru in alfisol and at the University of Agricultural Sciences (UAS), Dharwad, India, in vertisol fields. These geographical locations, ICRISAT-Patancheru at 78 $12^{\prime} \mathrm{E}, 1^{\circ} 24^{\prime} \mathrm{N}$, and $536 \mathrm{~m}$ altitude and Dharwad at $75^{\circ} 07^{\prime} \mathrm{E}, 15^{\circ} 13^{\prime} \mathrm{N}$, and $678 \mathrm{~m}$ altitude and two distinct seasons, rainy and post-rainy, represented diverse environments for investigating the variation and stability of the mini core collection for the nutritional traits. Each plot consisted of a single 4-m row with $60 \mathrm{~cm}$ spacing between rows at ICRISAT and $45 \mathrm{~cm}$ at UAS, Dharwad. The distance was $10 \mathrm{~cm}$ between the plants within each row. The seeds were planted at uniform depth. All required agronomic practices and plant protection measures against pests and diseases to raise a successful crop were followed. The experiments received $60 \mathrm{~kg} \mathrm{~N}, 90 \mathrm{~kg} \mathrm{P}_{2} \mathrm{O}_{5}$, and $60 \mathrm{~kg} \mathrm{~K} \mathrm{~K}_{2} \mathrm{O}$ $\mathrm{ha}^{-1}$ at UAS, Dharwad, with 10 irrigations in the post-rainy season and no irrigation (rainfed condition) during the rainy season. While at ICRISAT, the experiments received $60 \mathrm{~kg} \mathrm{P}_{2} \mathrm{O}_{5}$ and $400 \mathrm{~kg}$ gypsum ha ${ }^{-1}$ with 12 irrigations in the post-rainy and six irrigations in the rainy season, each irrigation totaling $5 \mathrm{~cm}$ of water. In each plot, five representative plants were tagged randomly to record various qualitative and quantitative traits. Data were recorded on a plot basis for days to $50 \%$ flowering (days after emergence to the stage when $50 \%$ of the plants had begun flowering), pod yield (kilograms 
per hectare), shelling percentage, and 100-seed weight (grams). The entire plot was harvested and immature pods were removed, air dried, cleaned, and weighed. The yield of five tagged plants was added to determine total plot yield. A $200 \mathrm{~g}$ matured pod sample was used to estimate shelling percentage. The seeds and shells were separated and shelling percentage was computed as follows.

Shelling percentage $=($ weight of seeds $\times 100) /$ (weight of seeds + weight of shells)

A random sample of 100 seeds was used to record 100-seed weight and protein content; oil content and fatty acid composition were measured from a random seed sample drawn from each genotype with near-infrared spectroscopy (NIRS) (Panford, 1990; Misra et al., 2000)

\section{Spectral Measurement of Near-Infrared Spectroscopy}

Near-infrared spectroscopy differed reflectance spectra were collected by a monochromatic near-infrared (NIR) spectrometer model 6500 (Foss NIRsystems, Inc., Laurel, MD) with spectral range of 400 to $2500 \mathrm{~nm}$ and with a light source of tungsten halogen lamps of $50 \mathrm{~W}$ and $12 \mathrm{~V}$. The spectrometer was equipped with a silicon detector. For analysis, the seeds were placed in a special adaptor of $3 \mathrm{~mm}$ thickness and $37 \mathrm{~mm}$ diameter with a central hole of $6 \mathrm{~mm}$. Spectral scanning was done by inserting the adaptor in a standard ring cup (IH-0325) and a sample was placed in the central hole. Before the spectral acquisition, a reference spectrum was collected from a standard check cell (IH-0324). The instrument diagnostics were performed to test the response of instrument, wavelength, and NIRS repeatability to avoid the effects of the surrounding environment on the instrument performance. The absorbance spectral data was recorded as log of reciprocal of reflectance ( $\log 1 / \mathrm{R}$ ) from 400 to $2500 \mathrm{~nm}$ at $8 \mathrm{~nm}$ intervals (Kim et al., 2007). The method permitted the analysis of about 40 samples per hour. Mathematical procedures on the spectral information were performed with the Win ISI II Project Manager Software version 1.5 (Infrasoft International, 2000).

\section{Calibration}

The NIR spectrometer (model 6500, Foss NIRsystems, Inc.) was calibrated using chemical reference methods with the application of multivariate regression models to interpret chemical information encoded in the spectral data. Original reflectance spectra were corrected before calibration by applying first and second derivative information, standard normal variate transformation, and de-trend scatter correlation, and four passes were used to eliminate outliers. A second derivative was calculated from log $1 / \mathrm{R}$ spectra of six data points and a smoothing over segments of four data points $(2,6,4$, and 1). This combination was selected after having tested six additional math treatments (not included) with and without spectral correlations and data pretreatments. The four data point treatment was either equal or superior in all cases based on standard error of cross-validation (SECV) and 1 VR (1 minus the ratio of unexplained variance to total variance) statistics. The calibrate equations were developed using principle component regression, partial least square, and modified partial least square (MPLS) regression models. Wavelength at an interval of $8 \mathrm{~nm}$ across the entire visible plus infrared spectrum was used for calibrations. The SE of calibration, SECV, $r$, and $1-\mathrm{VR}$ statistics were used to select the best calibration equation.

\section{Validation of Calibration Statistics}

The performance of the calibrated equation were maintained using the cross-validation and external validation and set of sample $(n=100)$; SECV, SE of prediction, and $r$ were used to determine the accuracy of prediction. The NIR spectrometer model 6500 (Foss NIRsystems, Inc.) was calibrated to analyze fatty acid composition of peanut using representative samples of both the botanical groups, that is, subsp. hypogaea and subsp. fastigiata. Standard normal variate and de-trend scatter correction with second derivative data pretreatment using the MPLS model was used to derive reliable equations with $r=0.90$ (Tillman et al., 2006). Using this equation, from each replication of the treatment given we analyzed five individual seeds from each sample that were of same size and of similar maturity and the average of five consistent scan results were taken for analysis.

Significant correlation $(r=0.89)$ between NIR and gas chromatography values after cross-validation indicated general usage of the calibrated equation for estimation of fatty acid composition of both subsp. fastigiata and subsp. hypogaea groups.

The best calibrated equations were used to determine protein content, oil content, and fatty acid composition in seeds of the mini core collection. From the data on eight fatty acid compositions determined, the major components of oleic acid and $\mathrm{O}: \mathrm{L}$ only were used in the present study, and data on other fatty acids are not given. The quality traits such as protein content, oil content, oleic acid (percent), and O:L were measured on a plot basis. Mean values were used for statistical analysis.

\section{Data Analysis}

Data were analyzed as per an $\alpha$ design following residual maximum likelihood analysis (Patterson and Thompson, 1971) with seasons as fixed and entries as random on GenStat 13.1 (VSN International, 2010). The components of phenotypic variance due to genotype $\left(\sigma^{2} \mathrm{~g}\right)$ for the entire mini core and for subsp. fastigiata and hypogaea, genotype $\times$ environment interaction $\left(\sigma^{2}\right.$ ge $)$ for the entire mini core, and fastigiata and hypogaea and their residual $\left(\sigma^{2} \mathrm{e}\right)$ and SEs were calculated. The significance among environments was tested using Wald (1943) statistics.

The stability analysis was performed following Eberhart and Russell (1966) to identify stable accessions for nutritional traits (protein content, oil content, oleic acid content, and O:L). Principal component analysis of data on all traits (13 agronomic and 11 quality) and of the selected 21 entries and control cultivars was performed (Hotelling, 1933). The mean observations for each trait were standardized by subtracting from each observation the mean value of the character and subsequently dividing by its respective SD. This resulted in standardized values for each trait with zero mean and SD of 1 . The standardized values were used to perform principal component analysis using GenStat 13.1 (VSN International, 2010). Cluster analysis using the Ward (1963) method was performed with scores of the first five principal components (PCs).

\section{RESULTS}

Residual maximum likelihood analysis of individual environment data indicated significant genotypic variances for 
Table 1. Estimates of variance from pooled analysis of peanut mini core collection for major nutritional quality and agronomic traits.

\begin{tabular}{|c|c|c|c|c|c|c|c|c|}
\hline $\begin{array}{c}\text { Source } \\
\text { of variation }{ }^{\dagger}\end{array}$ & $\begin{array}{l}\text { Protein } \\
(\%)\end{array}$ & $\begin{array}{l}\text { Oil } \\
(\%)\end{array}$ & $\begin{array}{c}\text { Oleic acid } \\
(\%)\end{array}$ & $\mathrm{O}: \mathrm{L}^{\ddagger}$ & $\begin{array}{c}\text { Days to } 50 \% \\
\text { flowering }\end{array}$ & $\begin{array}{l}\text { Pod yield } \\
\left(\mathrm{kg} \mathrm{ha}^{-1}\right)\end{array}$ & $\begin{array}{c}\text { Shelling } \\
\text { (\%) }\end{array}$ & $\begin{array}{l}100 \text {-seed } \\
\text { weight }(\mathrm{g})\end{array}$ \\
\hline$\sigma^{2} g$ & $18.625^{\star *}$ & $1.777^{\star \star}$ & $29.351^{* \star}$ & $0.5595^{\star \star}$ & $6.072^{\star \star}$ & $117504^{\star \star}$ & $4.69^{\star \star}$ & $32.62^{* \star}$ \\
\hline$\sigma^{2} \mathrm{~g} \times$ environment & $4.452^{\star \star}$ & $1.452^{* \star}$ & $11.624^{\star \star}$ & $0.1218^{\star \star}$ & $0.534^{\star *}$ & $181439^{\star \star}$ & $9.28^{\star \star}$ & $8.93^{\star \star}$ \\
\hline$\sigma^{2}$ fastigiata & $15.031^{\star \star}$ & $0.786^{\star \star}$ & $15.223^{\star *}$ & $0.13005^{\star \star}$ & $1.827^{\star \star}$ & $72925 n^{\S}$ & $7.18^{\star \star}$ & $23.82^{\star \star}$ \\
\hline$\sigma^{2}$ fastigiata $\times$ environment & $14.671^{\star \star}$ & $2.305^{\star \star}$ & $24.472^{\star \star}$ & $0.14491^{\star *}$ & $0.819^{* *}$ & $164804^{\star \star}$ & $4.13^{\star}$ & $8.09^{\star *}$ \\
\hline$\sigma^{2}$ hypogaea & $6.588^{\star \star}$ & $0.851^{\star \star}$ & $16.196^{\star \star}$ & $0.30277^{\star \star}$ & $1.921^{\star \star}$ & $140531^{\star}$ & $4.89^{*}$ & $32.14^{\star \star}$ \\
\hline$\sigma^{2}$ hypogaea $\times$ environment & $6.326^{\star \star}$ & $2.458^{\star \star}$ & $25.137^{\star \star}$ & $0.51222^{\star \star}$ & $0.146^{\star}$ & $195603^{\star \star}$ & $5.04^{*}$ & $9.82^{\star \star}$ \\
\hline$\sigma^{2}$ error & $3.022^{\star *}$ & $2.549^{\star \star}$ & $5.571^{\star \star}$ & $0.1^{\star \star}$ & $1.797^{\star \star}$ & $438360^{\star \star}$ & $29.19^{\star \star}$ & $15.67^{\star \star}$ \\
\hline
\end{tabular}

*Significant at $p=0.05$.

${ }^{*}$ Significant at $p=0.01$.

${ }^{\dagger} \sigma^{2}$, variance; $\sigma^{2} \mathrm{~g}$, variance due to genotype.

$\neq \mathrm{O}$ :L, oleic to linoleic acid ratio.

§ns, nonsignificant.

all four nutritional (protein content, oil content, oleic acid content, and $\mathrm{O}: \mathrm{L}$ ) and four agronomic (pod yield, days to $50 \%$ flowering, shelling percentage, and 100 -seed weight [g 100 seeds $^{-1}$ ]) traits (data not given). The pooled analysis of data collected over four environments revealed significant genotypic variance for all four nutritional traits and four agronomic traits (Table 1) indicating wide variation among accessions for the traits studied in the mini core collection. The genotype $x$ environment interaction variance was also significant for all the traits studied indicating the significant role of genotype, season, and location in affecting these traits under diverse environmental conditions. The genotypic variances within the subsp. fastigiata (98) and subsp. hypogaea (86) were significant for all the traits except for pod yield in subsp. fastigiata, indicating significant variation within each of the two subspecies germplasm collection also in the mini core collection. The variance due to interaction of genotype and environment was also significant in both groups of subspecies. The relative magnitude of genotypic variance vis-à-vis genotype $\times$ environment interaction variance was high (2.5 to 11 times) for most traits and almost equal for oil content indicating greater importance of genotypes whereas pod yield and shelling percentage had more influence from the environment.

The mean of the control cultivars in each of the subspecies was considered as a benchmark, and 18 accessions that were significantly superior to the respective control cultivars for the first nutritional trait, protein content, were selected and the same numbers of accessions were selected for the other three nutritional traits. These results along with agronomic performance are presented in Tables 2, 3, and 4. For high protein content (Table 2), 15 subsp. fastigiata accessions were significantly superior (29.11 to $31.29 \%$ ) to the control cultivar ICGS $44(24.37 \%)$ while three of the subsp. hypogaea accessions were superior (28.94 to 29.22\%) to the control cultivar ICGS 76 (23.77\%). On average the 15 subsp. fastigiata accessions had $41 \%$ more protein than mean protein content of the two subsp. fastigiata control cultivars (21.23) whereas the three subsp. hypogaea accessions had only 19\% more protein than the average for the two subsp. hypogaea control cultivars (24.43) (Table 2).These identified accessions, except ICG 36, ICG 1711, and ICG 3746 (which had linear response $\left[b_{i}\right]$ values significantly different than unity) and ICG 3421 and ICG 5051 (which had significant nonlinear response $\left.\left[\mathrm{S}^{2} \mathrm{~d}\right]\right)$, were found to be stable across the environments for protein content. The agronomic performance for these identified accessions was also good. On average the 15 subsp. fastigiata accessions produced about 5\% more pod yield than the average of two subsp. fastigiata control cultivars, and three lines, ICG 36, ICG 2019, ICG 4750 $\left(2638-2809 \mathrm{~kg} \mathrm{ha}^{-1}\right)$, yielded similar or better than the best subsp. fastigiata control, ICGS 44. ICG 36 contained 31.29\% protein and 5\% higher pod yield $\left(2809 \mathrm{~kg} \mathrm{ha}^{-1}\right)$ and had similar shelling percentage. However, 100 -seed weight of these identified accessions was less $(31.95$ to $38.19 \mathrm{~g}$ ) compared to the control cultivar ICGS 44 (49.1 g). In the subsp. hypogaea group, of the three entries identified, two of them, ICG 7963 (2756 kg ha-1) and ICG $13982\left(2729 \mathrm{~kg} \mathrm{ha}^{-1}\right)$, produced pod yield similar to the subsp. hypogaea control cultivar ICGS $76\left(2708 \mathrm{~kg} \mathrm{ha}^{-1}\right)$. The shelling percentage of these accessions was also similar to the control cultivar.

For oil content, 67 mini core accessions were significantly superior to ICGS 44 in the subsp. fastigiata group and three in subsp. hypogaea group had more oil than ICGS 76. The best 18 accessions identified for high oil content from the mini core collection (Table 3) indicated that 15 subsp. fastigiata (48.35 to 50.45\%) and three subsp. hypogaea (48.01 to $49.53 \%$ ) accessions were superior to their respective control cultivars, ICGS 44 (43.74\%) and ICGS 76 (46.09\%). On average the 15 subsp. fastigiata accessions had about 6.9\% more oil than average of two control cultivars $(45.78 \%)$ and the three subsp. hypogaea accessions had 6.5\% more oil than the mean oil content of two control cultivars (45.91). Most of the identified accessions were stable except ICG 397, ICG 3681, and ICG 5779 of subsp. fastigiata (significant $\mathrm{S}^{2} \mathrm{~d}$ ) and ICG 4746 and ICG 12000 of subsp. hypogaea (significant $\left.b_{i}\right)$. The pod yield of these identified accessions was similar (2228 to $2809 \mathrm{~kg} \mathrm{ha}^{-1}$ ) in 10 out of 15 accessions in the subsp. 
Table 2. Performance and stability of top 18 high protein $A$. hypogaea subsp. fastigiata and subsp. hypogaea accessions selected from the peanut mini core collection.

\begin{tabular}{|c|c|c|c|c|c|c|c|c|}
\hline $\begin{array}{c}\text { Subspecies } \\
\text { and accession }\end{array}$ & Origin & Protein (\%) & $b_{i}^{\dagger}$ & $S^{2} d^{\ddagger}$ & $\begin{array}{l}\text { Days to } 50 \% \\
\text { flowering }\end{array}$ & $\begin{array}{l}\text { Pod yield } \\
\left(\mathrm{kg} \mathrm{ha}^{-1}\right)\end{array}$ & $\begin{array}{c}\text { Shelling } \\
(\%)\end{array}$ & $\begin{array}{l}100 \text {-seed } \\
\text { weight }(\mathrm{g})\end{array}$ \\
\hline \multicolumn{9}{|l|}{ subsp. fastigiata } \\
\hline ICG 36 & India & 31.29 & $-1.74^{\star}$ & -0.97 & 24.87 & 2809 & 66.61 & 38.19 \\
\hline ICG 5779 & India & 30.99 & 2.31 & -1.33 & 25.50 & 2353 & 65.84 & 32.89 \\
\hline ICG 3421 & India & 30.62 & -0.19 & $2.78^{*}$ & 25.03 & 2228 & 67.16 & 34.76 \\
\hline ICG 3584 & India & 30.30 & 1.83 & -1.19 & 25.50 & 2498 & 64.30 & 36.94 \\
\hline ICG 2019 & India & 30.05 & 3.30 & 0.75 & 23.44 & 2649 & 67.60 & 33.51 \\
\hline ICG 1519 & India & 29.96 & -0.10 & 1.19 & 24.55 & 2379 & 66.83 & 35.23 \\
\hline ICG 4729 & China & 29.85 & -0.48 & 2.28 & 25.66 & 2340 & 62.43 & 36.01 \\
\hline ICG 1973 & India & 29.82 & 2.28 & -0.58 & 24.08 & 2448 & 65.07 & 34.60 \\
\hline ICG 3746 & Argentina & 29.73 & $4.97^{\star \star}$ & -1.11 & 25.19 & 2374 & 67.71 & 33.04 \\
\hline ICG 4750 & Paraguay & 29.65 & 0.32 & 1.22 & 22.33 & 2638 & 67.60 & 35.85 \\
\hline ICG 12988 & India & 29.55 & 1.74 & 2.55 & 24.39 & 2518 & 64.96 & 31.95 \\
\hline ICG 4911 & Malawi & 29.52 & 0.39 & -0.24 & 25.19 & 2529 & 65.62 & 35.38 \\
\hline ICG 2106 & India & 29.36 & 2.05 & -1.41 & 25.03 & 2481 & 70.13 & 35.69 \\
\hline ICG 81 & Unknown & 29.30 & 2.07 & -1.43 & 25.19 & 2570 & 66.72 & 34.45 \\
\hline ICG 1711 & Bolivia & 29.11 & $-1.40^{\star}$ & -0.86 & 24.71 & 2233 & 62.21 & 33.41 \\
\hline \multicolumn{9}{|l|}{ Control } \\
\hline Gangapuri & India & 18.08 & 2.12 & -1.41 & 21.38 & 2043 & 64.96 & 39.90 \\
\hline ICGS 44 & India & 24.37 & 1.07 & -1.05 & 25.50 & 2686 & 67.05 & 49.10 \\
\hline \multicolumn{9}{|l|}{ subsp. hypogaea } \\
\hline ICG 7963 & United States & 29.22 & 2.47 & -1.43 & 25.03 & 2756 & 63.75 & 42.87 \\
\hline ICG 5051 & United States & 29.02 & 0.22 & $5.23^{\star \star}$ & 25.98 & 1279 & 60.22 & 49.88 \\
\hline ICG 13982 & United States & 28.94 & 1.51 & -1.42 & 25.19 & 2729 & 64.41 & 42.40 \\
\hline \multicolumn{9}{|l|}{ Control } \\
\hline ICGS 76 & India & 23.77 & -0.27 & $3.23^{\star}$ & 27.41 & 2708 & 68.26 & 50.19 \\
\hline M 13 & India & 25.08 & $3.64^{*}$ & -0.50 & 28.20 & 2423 & 67.71 & 51.60 \\
\hline Trial mean & & 23.71 & & & 25.6 & 2289 & 64.55 & 40.92 \\
\hline $\mathrm{SE} \pm$ & & 1.706 & & & 0.5464 & 175.7 & 1.789 & 1.565 \\
\hline LSD (5\%) & & 4.732 & & & 1.516 & 487.6 & 4.965 & 4.343 \\
\hline CV (\%) & & 7.443 & & & 5.355 & 19.22 & 8.356 & 9.686 \\
\hline Heritability $\left(h^{2}\right)$ & & 93.16 & & & 91.55 & 48.21 & 34.47 & 82.64 \\
\hline
\end{tabular}

*Significant at $p=0.05$.

${ }^{* *}$ Significant at $p=0.01$.

${ }^{t} b_{i}$, linear response.

${ }^{\ddagger} \mathrm{S}^{2} \mathrm{~d}$, nonlinear response.

fastigiata group compared to control cultivar ICGS 44 (2686 $\left.\mathrm{kg} \mathrm{ha}^{-1}\right)$. ICG $36\left(48.53 \%\right.$ oil and $\left.2809 \mathrm{~kg} \mathrm{ha}^{-1}\right)$ and ICG $1142\left(48.79 \%\right.$ oil and $\left.2709 \mathrm{~kg} \mathrm{ha}^{-1}\right)$ produced higher pod yield with similar shelling percentage and days to $50 \%$ flowering. However, the three subsp. hypogaea accessions yielded (1279 to $1522 \mathrm{~kg} \mathrm{ha}^{-1}$ ) lower than ICGS $76\left(2708 \mathrm{~kg} \mathrm{ha}^{-1}\right)$.

The major fatty acid determining oil quality is oleic acid content, and 18 top accessions were identified with high oleic acid, of which seven belonged to the subsp. fastigiata (57.55 to $61.88 \%)$ and 11 to the subsp. hypogaea (57.63 to $73.36 \%$ ) group (Table 4). The selected accessions were superior to the respective controls, ICGS 44 (47.85\%) and M 13 (54.9\%). The seven subsp. fastigiata accessions had on average $33 \%$ more oleic acid than the mean of two control cultivars whereas the 11 subsp. hypogaea accessions had 7\% more oleic acid than mean of control cultivars. Six subsp. hypogaea accessions (ICG 2381, ICG 6766, ICG 7243, ICG
10185, ICG 12276, and ICG 15190) and all the subsp. fastigiata accessions except ICG 6022 were stable across environments. The high oleic $(>60 \%)$ subsp. hypogaea accessions (ICG 2381, ICG 10185, ICG 15419, ICG 12276, ICG 7243, and ICG 6766) except the top accession ICG $2381\left(73.36 \%\right.$ and $\left.2051 \mathrm{~kg} \mathrm{ha}^{-1}\right)$ produced similar pod yield $\left(2426-2640 \mathrm{~kg} \mathrm{ha}^{-1}\right)$. ICG $15419\left(3712 \mathrm{~kg} \mathrm{ha}^{-1}\right)$ produced significantly higher pod yield than control cultivar ICGS $76\left(2708 \mathrm{~kg} \mathrm{ha}^{-1}\right)$. The best three subsp. fastigiata accessions (ICG 6022, ICG 12625, and ICG 11088) recorded $\geq 60 \%$ oleic acid with higher pod yield (2669-3284 $\left.\mathrm{kg} \mathrm{ha}^{-1}\right)$. The identification of ICG 2381, a stable accession, with nonsignificant $\mathrm{S}^{2} \mathrm{~d}(2.86)$ and $\mathrm{b}_{\mathrm{i}}(-0.25)$ values and high mean oleic acid $(73.36 \%)$ is a significant finding.

Based on the relative proportion of oleic acid to linoleic acid computed as O:L, 18 top accessions were identified from subsp. fastigiata (9 accessions) and subsp. hypogaea ( 9 
Table 3. Performance and stability of top 18 high oil $A$. hypogaea subsp. fastigiata and subsp. hypogaea accessions selected from the peanut mini core collection.

\begin{tabular}{|c|c|c|c|c|c|c|c|c|}
\hline $\begin{array}{c}\text { Subspecies and } \\
\text { accession }\end{array}$ & Origin & $\begin{array}{l}\text { Oil } \\
(\%)\end{array}$ & $b_{i}^{\dagger}$ & $\mathrm{S}^{2} \mathrm{~d}^{\ddagger}$ & $\begin{array}{l}\text { Days to } \\
50 \% \text { flowering }\end{array}$ & $\begin{array}{l}\text { Pod yield } \\
\left(\mathrm{kg} \mathrm{ha}^{-1}\right)\end{array}$ & $\begin{array}{l}\text { Shelling } \\
\text { (\%) }\end{array}$ & $\begin{array}{l}100 \text {-seed } \\
\text { weight }(\mathrm{g})\end{array}$ \\
\hline \multicolumn{9}{|l|}{ subsp. fastigiata } \\
\hline ICG 442 & United States & 50.45 & 4.27 & 0.52 & 23.92 & 2347 & 67.82 & 32.58 \\
\hline ICG 397 & United States & 49.72 & 0.30 & $4.19^{\star}$ & 21.69 & 2598 & 65.73 & 40.06 \\
\hline ICG 5779 & India & 49.24 & 1.50 & $2.69^{\star}$ & 25.5 & 2353 & 65.84 & 32.89 \\
\hline ICG 4955 & India & 49.09 & 2.41 & -0.85 & 23.28 & 2428 & 67.49 & 40.99 \\
\hline ICG 14710 & Cameroon & 49.09 & 2.99 & -1.26 & 22.01 & 1997 & 67.27 & 40.84 \\
\hline ICG 6201 & Cuba & 48.96 & 1.99 & -0.73 & 21.85 & 2031 & 64.63 & 36.32 \\
\hline ICG 1415 & Senegal & 48.85 & 2.01 & 0.11 & 25.03 & 1364 & 57.14 & 32.42 \\
\hline ICG 1142 & Benin & 48.79 & -0.78 & -1.06 & 23.92 & 2709 & 68.04 & 42.71 \\
\hline ICG 3681 & United States & 48.75 & 2.50 & $0.82^{\star *}$ & 22.17 & 1967 & 63.97 & 38.81 \\
\hline ICG 13856 & Uganda & 48.69 & 2.64 & -0.83 & 22.01 & 2375 & 64.96 & 39.44 \\
\hline ICG 36 & India & 48.53 & -0.09 & -0.22 & 24.87 & 2809 & 66.61 & 38.19 \\
\hline ICG 1519 & India & 48.51 & 0.46 & 8.23 & 24.55 & 2379 & 66.83 & 35.23 \\
\hline ICG 3421 & India & 48.5 & 0.92 & -0.87 & 25.03 & 2228 & 67.16 & 34.76 \\
\hline ICG 3673 & Korea & 48.45 & 2.28 & -1.31 & 24.08 & 2308 & 68.15 & 41.93 \\
\hline ICG 115 & India & 48.35 & 0.70 & -0.73 & 22.17 & 1884 & 65.62 & 40.53 \\
\hline \multicolumn{9}{|l|}{ Control } \\
\hline Gangapuri & India & 47.82 & $5.15^{\star}$ & -1.27 & 21.38 & 2043 & 64.96 & 39.9 \\
\hline ICGS 44 & India & 43.74 & $4.82^{*}$ & -1.30 & 25.5 & 2686 & 67.05 & 49.1 \\
\hline \multicolumn{9}{|l|}{ subsp. hypogaea } \\
\hline ICG 4746 & Israel & 49.53 & $-2.80^{\star}$ & -1.35 & 28.68 & 1339 & 64.74 & 50.04 \\
\hline ICG 12000 & Mali & 49.11 & $4.83^{*}$ & -0.31 & 28.05 & 1279 & 62.54 & 36.32 \\
\hline ICG 10479 & Uruguay & 48.01 & 2.92 & -1.31 & 26.93 & 1522 & 55.71 & 37.1 \\
\hline \multicolumn{9}{|l|}{ Control } \\
\hline ICGS 76 & India & 46.09 & 3.34 & -0.61 & 27.41 & 2708 & 68.26 & 50.19 \\
\hline M 13 & India & 45.72 & 1.89 & -1.14 & 28.2 & 2423 & 67.71 & 51.6 \\
\hline Trial mean & & 46.35 & & & 25.6 & 2289 & 64.55 & 40.92 \\
\hline $\mathrm{SE} \pm$ & & 0.9801 & & & 0.5464 & 175.7 & 1.789 & 1.565 \\
\hline LSD (5\%) & & 2.718 & & & 1.516 & 487.6 & 4.965 & 4.343 \\
\hline CV (\%) & & 3.449 & & & 5.355 & 19.22 & 8.356 & 9.686 \\
\hline Heritability $\left(h^{2}\right)$ & & 81.58 & & & 91.55 & 48.21 & 34.47 & 82.64 \\
\hline
\end{tabular}

${ }^{*}$ Significant at $p=0.05$.

${ }^{*}$ Significant at $p=0.01$.

${ }^{\dagger} b_{i}$, linear response.

$\neq \mathrm{S}^{2} \mathrm{~d}$, nonlinear response.

accessions) groups (Table 4). The identified subsp. fastigiata accessions had significantly higher (2.65 to 3.31) O:L compared to the control cultivar ICGS 44 (1.671). All the identified accessions except ICG 5475 and ICG 15287 of subsp. fastigiata were stable across the environments. The best three stable accessions (ICG 6022, ICG 1274, and ICG 12625) with $\geq 3.0 \mathrm{O}: \mathrm{L}$ and good agronomic traits can be utilized in genetic improvement programs. ICG 2381 from subsp. hypogaea has been identified as an outstanding (6.91) and stable accession for O:L and can be a good donor parent in crop improvement programs. Five other accessions (ICG 10185, ICG 7243, ICG 6766, ICG 12276, and ICG 15419) with $\geq 3.0$ O:L and good agronomic performance and stable across environments have been identified.

The 21 accessions identified with two and more combined nutritional traits are listed in Table 5 and depicted in Fig. 1. ICG 36, ICG 1519, ICG 3421, and ICG 5779 recorded higher protein and oil contents. ICG 36 flowered in $25 \mathrm{~d}$ and produced $2809 \mathrm{~kg} \mathrm{ha}^{-1}$ pod with $100-$ seed weight of 38.19 g. ICG 6022 (61.8\% oleic acid and $3.31 \mathrm{O}: \mathrm{L})$ and ICG 11088 (60.26\% oleic and $2.865 \mathrm{O}: \mathrm{L})$ recorded higher pod yield (3229 and $3284 \mathrm{~kg} \mathrm{ha}^{-1}$, respectively). Among the 10 subsp. hypogaea accessions ICG 2381 had high oleic acid (73.36\%) and O:L (6.91). ICG 15419 with $61.12 \%$ oleic acid and 3.03 O:L recorded significantly higher $\left(3712 \mathrm{~kg} \mathrm{ha}^{-1}\right)$ pod yield compared to control

In case of nutritional traits, O:L was highly correlated with oleic acid content $(r=0.942)$ whereas protein and oil contents were unrelated to each other $(r=-0.002)$. However, both protein and oil were negatively correlated with oleic acid (protein-oleic acid, $r=-0.234$, and oil-oleic acid, $r=-0.656$ ) and $\mathrm{O}: \mathrm{L}$ ratio (protein-O:L, $r=-0.176$ and oil-O: L, $r=-0.646)$. Except for protein content $(r=$ 0.186), none of the nutritional traits were correlated with 
Table 4. Performance and stability of top 18 high oleic acid and 18 high oleic to linoleic acid ratio (O:L) A. hypogaea subsp. fastigiata and subsp. hypogaea accessions selected from peanut mini core collection.

\begin{tabular}{|c|c|c|c|c|c|c|c|c|c|c|c|}
\hline $\begin{array}{l}\text { Subspecies and } \\
\text { accessions }\end{array}$ & Origin & $\begin{array}{c}\text { Oleic } \\
\text { acid (\%) }\end{array}$ & $b_{i}^{\dagger}$ & $S^{2} d^{\ddagger}$ & O:L & $b_{i}$ & $S^{2} d$ & $\begin{array}{l}\text { Days to } 50 \% \\
\text { flowering }\end{array}$ & $\begin{array}{l}\text { Pod yield } \\
\left(\mathrm{kg} \mathrm{ha}^{-1}\right)\end{array}$ & $\begin{array}{c}\text { Shelling } \\
\%\end{array}$ & $\begin{array}{l}\text { 100-seed } \\
\text { weight }(\mathrm{g})\end{array}$ \\
\hline \multicolumn{12}{|l|}{ subsp. fastigiata } \\
\hline ICG 6022 & Sudan & 61.88 & 1.12 & $8.04^{*}$ & 3.31 & 2.06 & -0.03 & 23.9 & 3229 & 61.2 & 53.2 \\
\hline ICG 12625 & Ecuador & 61.25 & 0.94 & 0.25 & 3.07 & 1.46 & 0.06 & 23.8 & 2669 & 62.3 & 46.5 \\
\hline ICG 11088 & Peru & 60.26 & 0.91 & -2.00 & 2.87 & 0.32 & -0.05 & 25.2 & 3284 & 62.5 & 40.1 \\
\hline ICG 1274 & Indonesia & 59.19 & 0.06 & -2.42 & 3.26 & 2.45 & -0.02 & 22.5 & 2327 & 65.0 & 48.5 \\
\hline ICG 15287 & Brazil & 58.58 & 2.14 & 3.73 & 2.79 & 2.11 & $0.14^{*}$ & 21.5 & 2300 & 64.7 & 42.7 \\
\hline ICG 6375 & Unknown & 57.84 & 1.67 & -0.02 & 2.78 & 0.39 & -0.02 & 25.2 & 1654 & 67.5 & 26.0 \\
\hline ICG 5221 & Argentina & 57.55 & 1.39 & -1.93 & 2.87 & 3.06 & -0.04 & 22.3 & 2852 & 62.8 & 42.1 \\
\hline ICG 8106§ & Peru & 57.40 & 1.45 & 0.22 & 2.77 & 1.06 & -0.05 & 23.6 & 2264 & 65.8 & 36.6 \\
\hline ICG 5475§ & Kenya & 55.47 & -2.37 & 0.16 & 2.65 & $6.29^{\star \star}$ & -0.04 & 23.6 & 1607 & 65.4 & 40.7 \\
\hline \multicolumn{12}{|l|}{ Control } \\
\hline Gangapuri & India & 42.00 & 3.18 & -2.69 & 1.21 & 1.71 & $0.09^{\star \star}$ & 21.4 & 2043 & 65.0 & 39.9 \\
\hline ICGS 44 & India & 47.85 & 2.60 & 1.86 & 1.67 & 0.85 & $0.42^{* *}$ & 25.5 & 2686 & 67.1 & 49.1 \\
\hline \multicolumn{12}{|l|}{ subsp. hypogaea } \\
\hline ICG 2381 & Brazil & 73.36 & -0.25 & 2.86 & 6.91 & 4.20 & 0.04 & 27.7 & 2051 & 64.2 & 50.8 \\
\hline ICG 10185 & United States & 62.28 & 0.73 & -2.76 & 3.55 & -0.55 & -0.01 & 28.5 & 2461 & 64.0 & 48.0 \\
\hline ICG 15419 & Ecuador & 61.12 & $3.54^{\star}$ & -0.99 & 3.03 & 0.44 & 0.03 & 23.3 & 3712 & 59.3 & 50.0 \\
\hline ICG 12276 & Bolivia & 61.03 & 1.33 & -2.42 & 3.05 & 1.02 & -0.05 & 24.9 & 2640 & 62.4 & 45.8 \\
\hline ICG 7243 & United States & 60.83 & 0.88 & -1.60 & 3.23 & 0.67 & -0.05 & 28.2 & 2253 & 64.2 & 42.1 \\
\hline ICG 6766 & United States & 60.09 & 2.33 & -0.75 & 3.14 & 1.61 & -0.05 & 27.1 & 2426 & 62.1 & 53.6 \\
\hline ICG 928 & Unknown & 58.45 & $-1.77^{\star}$ & $45.90^{\star \star}$ & 2.88 & 4.37 & -0.03 & 27.7 & 2432 & 65.6 & 44.0 \\
\hline ICG 3053 & India & 58.29 & 2.51 & $22.83^{\star \star}$ & 2.90 & 1.55 & -0.04 & 28.5 & 2800 & 65.4 & 47.4 \\
\hline ICG 15190 & Costa Rica & 58.17 & 2.15 & 2.61 & 2.94 & 2.49 & 0.01 & 28.2 & 2749 & 65.3 & 45.8 \\
\hline ICG 11426" & India & 58.13 & $4.27^{\star \star}$ & -0.03 & 2.52 & -0.77 & 0.05 & 27.3 & 2661 & 65.5 & 50.4 \\
\hline ICG $2777^{\natural}$ & India & 57.63 & -0.37 & $34.75^{\star \star}$ & 2.83 & 1.52 & $0.57^{\star \star}$ & 28.7 & 2531 & 66.7 & 39.3 \\
\hline \multicolumn{12}{|l|}{ Control } \\
\hline ICGS 76 & India & 58.38 & $3.57^{\star}$ & -1.72 & 2.70 & 0.70 & -0.05 & 27.4 & 2708 & 68.3 & 50.2 \\
\hline M 13 & India & 54.90 & 1.45 & -2.75 & 2.53 & 1.26 & -0.04 & 28.2 & 2423 & 67.7 & 51.6 \\
\hline Trial mean & & 48.28 & & & 1.83 & & & 25.6 & 2289 & 64.6 & 40.9 \\
\hline $\mathrm{SE} \pm$ & & 2.622 & & & 0.321 & & & 0.546 & 175.7 & 1.79 & 1.57 \\
\hline LSD (5\%) & & 7.27 & & & 0.89 & & & 1.5 & 487.6 & 5 & 4.3 \\
\hline CV (\%) & & 4.86 & & & 22.20 & & & 5.4 & 19.2 & 8.4 & 9.7 \\
\hline Heritability $\left(h^{2}\right)$ & & 93.20 & & & 92.80 & & & 91.6 & 48.2 & 34.5 & 82.6 \\
\hline
\end{tabular}

*Significant at $p=0.05$.

${ }^{*}$ Significant at $p=0.01$.

${ }^{t} b_{i}$, linear response.

$\neq \mathrm{S}^{2} \mathrm{~d}$, nonlinear response.

§Selected only for O:L.

"Selected only for oleic acid.

pod yield $(r=-0.024$ with oil, 0.017 with oleic acid, and 0.030 with $\mathrm{O}: \mathrm{L})$. While oil content was negatively correlated $(r=-0.297)$, oleic acid $(r=0.440)$ and O:L $(r=$ $0.434)$ were positively correlated with 100 -seed weight.

Principal component analysis, using data of eight traits of 21 selected accessions and four control cultivars, was performed. The first principal component (PC1) explained $48.5 \%$ variation, followed by PC2 (22.5\% variation), PC3 (13.0\% variation), PC4 (5.5\% variation), and PC5 (5.1\% variation). Cluster analysis based on scores on first five PCs (94.6\% variation) delineated the accessions in three clusters (Fig. 2). Accessions were delineated on the basis of high oleic acid (60.7\%), high pod yield (2836 kg ha-1), and high 100-seed weight (46.8 g) in cluster1, high O:L (3.39) and early flowering $(23.7 \mathrm{~d})$ in cluster2, and high protein (26.6\%) and high shelling percentage (66.6\%) in cluster 3.

\section{DISCUSSION}

The results of evaluation of the mini core collection over two locations (Patancheru and Dharwad) in two seasons (2008 rainy and 2008/2009 post-rainy) indicated the presence of variation for the four nutritional traits protein content, oil content, oleic acid content, and O:L. The magnitude of variation was comparatively high for protein content in subsp. fastigiata accessions while it was high for $\mathrm{O}: \mathrm{L}$ in subsp. hypogaea, and for two other traits, oil content and oleic acid content, the magnitude of variation was almost similar in both the groups of genotypes. The 
Table 5. Performance of $21 A$. hypogaea subsp. fastigiata and subsp. hypogaea accessions selected for superior performance over mean of control cultivars for two or more nutritional traits from the peanut mini core collection.

\begin{tabular}{|c|c|c|c|c|c|}
\hline $\begin{array}{l}\text { Subspecies } \\
\text { and accession }\end{array}$ & Origin & $\begin{array}{l}\text { Protein } \\
\text { (\%) }\end{array}$ & $\begin{array}{l}\text { Oil } \\
(\%)\end{array}$ & $\begin{array}{c}\text { Oleic } \\
\text { acid (\%) }\end{array}$ & $\mathrm{O}: \mathrm{L}^{\dagger}$ \\
\hline \multicolumn{6}{|l|}{ subsp. fastigiata } \\
\hline ICG 36 & India & 31.29 & 48.53 & 43.87 & 1.388 \\
\hline ICG 5779 & India & 30.99 & 49.24 & 41.62 & 1.276 \\
\hline ICG 3421 & India & 30.62 & 48.5 & 42.23 & 1.304 \\
\hline ICG 1519 & India & 29.96 & 48.51 & 40.29 & 1.194 \\
\hline ICG 1274 & Indonesia & 24.11 & 44.68 & 59.19 & 3.261 \\
\hline ICG 5221 & Argentina & 23.41 & 46.11 & 57.55 & 2.872 \\
\hline ICG 15287 & Brazil & 20.54 & 45.24 & 58.58 & 2.791 \\
\hline ICG 6375 & Unknown & 20.11 & 45.72 & 57.84 & 2.781 \\
\hline ICG 12625 & Ecuador & 18.84 & 44.78 & 61.25 & 3.07 \\
\hline ICG 6022 & Sudan & 18.31 & 46.54 & 61.88 & 3.312 \\
\hline ICG 11088 & Peru & 16.3 & 44.41 & 60.26 & 2.865 \\
\hline \multicolumn{6}{|l|}{ Control } \\
\hline Gangapuri & India & 18.08 & 47.82 & 42 & 1.208 \\
\hline ICGS 44 & India & 24.37 & 43.74 & 47.85 & 1.671 \\
\hline \multicolumn{6}{|l|}{ subsp. hypogaea } \\
\hline ICG 3053 & India & 23.91 & 44.93 & 58.29 & 2.9 \\
\hline ICG 10185 & United States & 23.89 & 45.16 & 62.28 & 3.546 \\
\hline ICG 928 & Unknown & 23.6 & 44.17 & 58.45 & 2.876 \\
\hline ICG 2777 & India & 23.4 & 44.82 & 57.63 & 2.829 \\
\hline ICG 6766 & United States & 23.39 & 47.06 & 60.09 & 3.138 \\
\hline ICG 15190 & Costa Rica & 23.28 & 45.21 & 58.17 & 2.941 \\
\hline ICG 7243 & United States & 23.23 & 45.65 & 60.83 & 3.231 \\
\hline ICG 12276 & Bolivia & 22.92 & 47.41 & 61.03 & 3.049 \\
\hline ICG 2381 & Brazil & 19.96 & 39.11 & 73.36 & 6.908 \\
\hline ICG 15419 & Ecuador & 17.18 & 44.42 & 61.12 & 3.025 \\
\hline \multicolumn{6}{|l|}{ Control } \\
\hline ICGS 76 & India & 23.77 & 46.09 & 58.38 & 2.701 \\
\hline M 13 & India & 25.08 & 45.72 & 54.9 & 2.525 \\
\hline Trial mean & & 23.71 & 46.35 & 48.28 & 1.827 \\
\hline $\mathrm{SE} \pm$ & & 1.706 & 0.9801 & 2.622 & 0.3209 \\
\hline LSD (5\%) & & 4.732 & 2.718 & 7.274 & 0.8901 \\
\hline CV (\%) & & 7.443 & 3.449 & 4.863 & 22.24 \\
\hline Heritability $\left(h^{2}\right)$ & & 93.16 & 81.58 & 93.24 & 92.78 \\
\hline
\end{tabular}

†O:L, oleic to linoleic acid ratio.

significance of $\sigma^{2}$ ge was indicative of the effect of environments on genotypes in the expression of these nutritional quality traits. The $\sigma^{2}$ ge was further partitioned into genotype $\times$ location interaction $\left(\sigma^{2} \mathrm{gl}\right)$ and genotype $\times$ season interaction $\left(\sigma^{2} \mathrm{gs}\right)$. The variances due to $\sigma^{2} \mathrm{gl}$ and $\sigma^{2}$ gs were of similar magnitude for protein content whereas for other three traits (oil, oleic acid, and $\mathrm{O}: \mathrm{L}$ ), $\sigma^{2} \mathrm{gl}$ was greater than $\sigma^{2}$ gs. Significant genotypic interactions with growing season and geographic location have been reported earlier for fatty acid profiles (Holaday and Pearson, 1974, Norden et al., 1987). Considering proportion of variance due to genotype $\times$ environment interaction to the total phenotypic variance (Upadhyaya, 2005), oil content (14.76\%) was least stable followed by oleic acid $(8.82 \%)$ whereas the protein and $\mathrm{O}: \mathrm{L}$ were the most stable nutritional traits.
Superior accessions for each of the four nutritional traits have been identified. The mean protein content of the selected subsp. fastigiata (29.84\%) and subsp. hypogaea (29.03\%) was much higher compared to control cultivars $(22.82 \%)$ and the mean of all subsp. fastigiata (24.5\%) and subsp. hypogaea $(22.9 \%)$ accessions in the mini core collection. The subsp. fastigiata accessions identified have higher protein content, 5 to $7 \%$, with similar pod yield as compared to high yielding control cultivars and will provide an opportunity for breeders to choose genetically diverse accessions for enhancing protein content in confectionary cultivars. ICG 442, among subsp. fastigiata group, recorded $\geq 50 \%$ mean oil content. The mean oil content of the selected accessions was greater (48.8\%) compared to control cultivars $(45.8 \%)$.

Although high oleic acid with $>70 \%$ germplasm lines were identified earlier (Norden et al., 1987), they are not available for global research and development. The present study resulted in identification of the stable and high oleic (73.36\%) subsp. hypogaea accession (ICG 2381) with similar 100 -seed weight $(50.8 \mathrm{~g})$ to the control cultivars. This could be the valuable source for peanut breeders for genetic enhancement of oleic acid and to enhance the shelf life of peanut products. The other five accessions (ICG 10185, ICG 15419, ICG 12276, ICG 7243, and ICG 11088) with $\geq 60 \%$ oleic acid and with either similar or superior performance for agronomic traits could be the additional resources for recombinant breeding. The $\mathrm{O}: \mathrm{L}$ of these identified lines was also higher indicating their superiority over the control cultivars. The selected accessions of both subsp. hypogaea (60.85\%) and subsp. fastigiata (59.51\%) had higher oleic acid content compared to the mean of all subsp. hypogaea (52.9\%) and subsp. fastigiata (44.5\%) accessions and control cultivars (50.78\%).

The correlations among nutrient and agronomic traits indicated that simultaneous selection for various nutritional and agronomic traits, such as high protein and high pod yield and high oleic acid content and O:L with high 100seed weight was possible in the mini core collection. Also, the selection for protein did not adversely affect oil content.

Twenty-one diverse accessions (11 subsp. fastigiata and 10 subsp. hypogaea) with two or more desired trait combinations have been identified (Table 5). The agronomic performance of the selected accessions for four nutritional traits is graphically represented in Fig. 1. Among these, subsp. fastigiata accessions with combined traits of both high protein content and high oil content or high oleic acid and high O:L were identified whereas in subsp. hypogaea only high oleic acid and high O:L accessions were identified. The identified accessions were geographically as well as genotypically diverse (Fig. 2). Interestingly, three of the control cultivars, one subsp. fastigiata (ICGS 44) and two subsp. hypogaea (M 13 and ICGS 76) were grouped in the same cluster and the identified accessions were found to be diverse from these genotypes. The genetic enhancement of these nutritional traits could be easy as they have higher heritability $(>80 \%)$. 


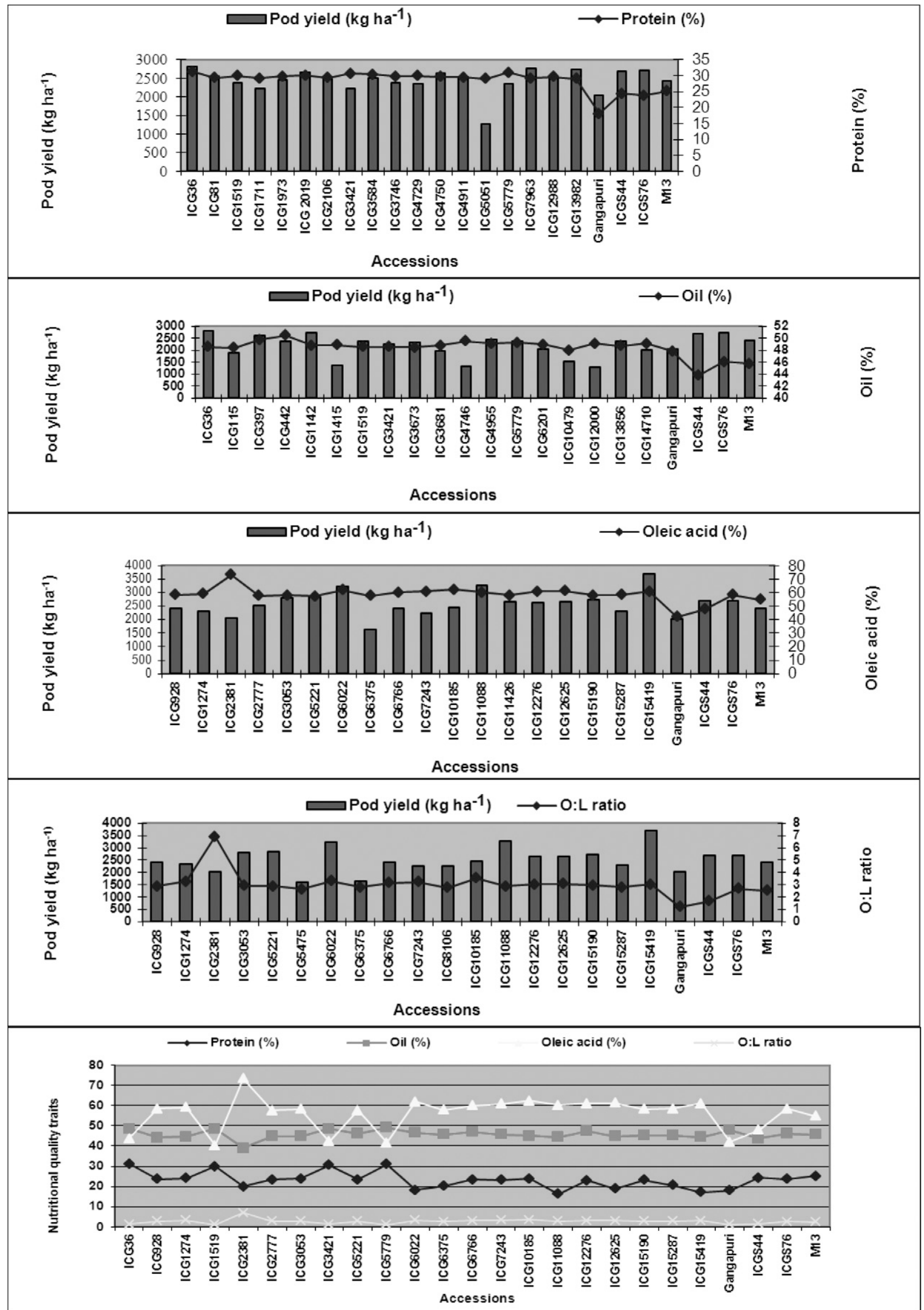

Figure 1. Graphical representation of performance of superior accessions selected for high protein content, oil content, oleic acid content, and oleic to linoleic acid ratio $(\mathrm{O}: \mathrm{L})$ and combined nutritional traits in the mini core collection of peanut. 


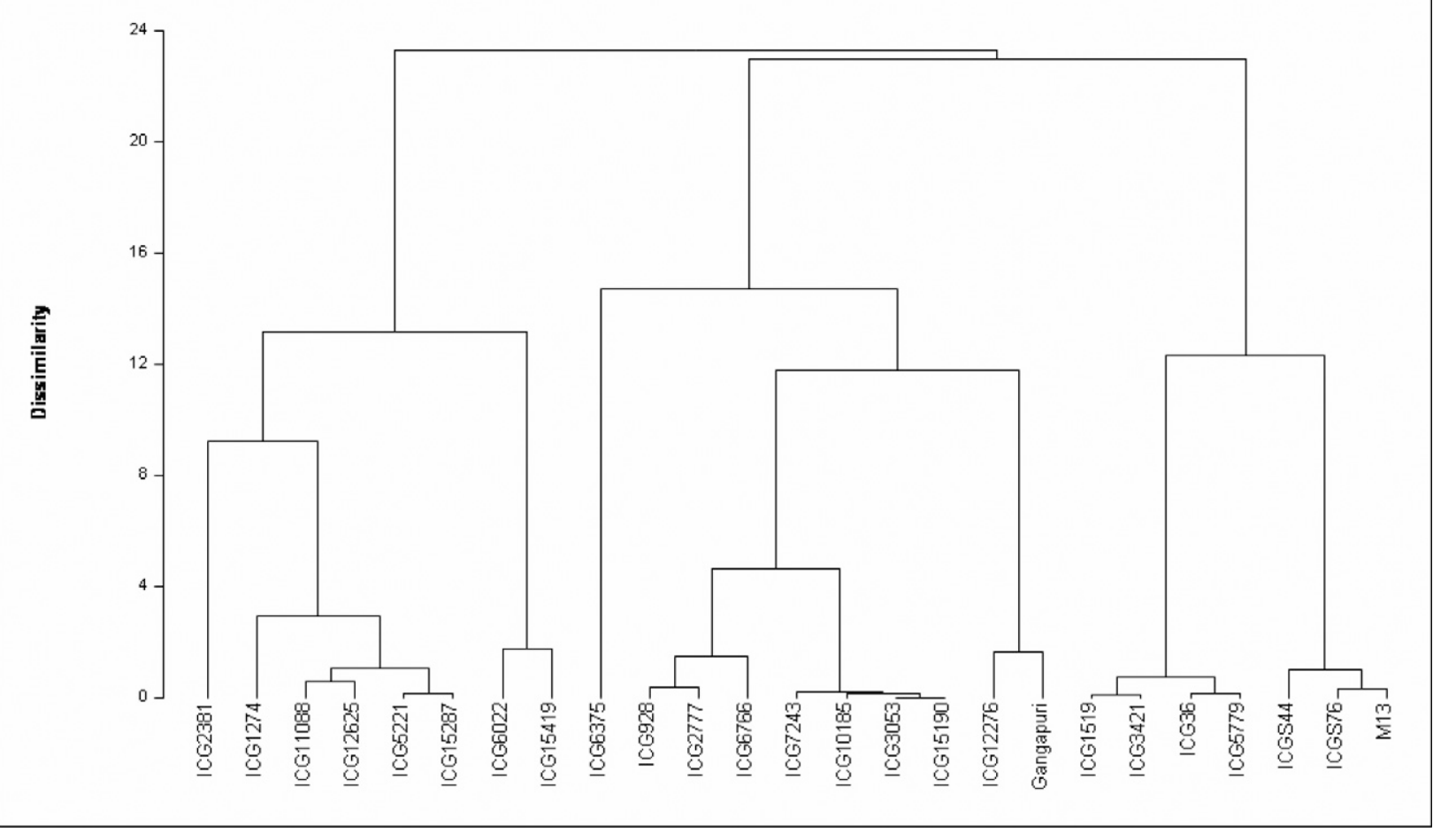

Figure 2. Dendrogram of the selected 21 superior peanut mini core accessions and four control cultivars based on scores of first five principal component (94.6\% variation).

Several lines identified for nutritional traits in this study (Tables 2 through 5) have also been reported as resistant or tolerant to important abiotic (drought, salinity) and biotic (diseases) stresses. The high protein lines, ICG 1519, ICG 1711, and ICG 2106, have also been reported as tolerant to salinity (Srivastava, 2010), ICG 2106 also being tolerant to drought (Upadhyaya, 2005) and ICG 4750 resistant to aflatoxin contamination (Jiang et al., 2010). Similarly, the high oil line ICG 442 has been reported as tolerant to salinity and ICG 4746 and ICG 12000 as resistant to rust (Kusuma et al., 2007), high oleic acid lines ICG 7243 as tolerant to drought (Upadhyaya, 2005), ICG 11088 as resistant to rust, and ICG 12625 as resistant to aflatoxin and late leaf spots (Kusuma et al., 2007), and the lines with high O:L, ICG 6022, as resistant to rust, late leaf spots, and early leaf spots (ICRISAT, 2009) and ICG 6766 as tolerant to drought (Upadhyaya, 2005). The agronomic desirability of these lines is of particular significance in meeting the needs of peanut breeders for traitspecific, diverse, and agronomically desirable germplasm lines for use in their breeding programs to develop peanut cultivars with desirable combinations of traits and with a broad genetic base. Limited quantity of seeds of the lines identified in this study is available for research using Standard Material Transfer Agreement.

\section{References}

Carlson, S.E. 1995. The role of PUFA in infant nutrition. Inform 6:940-946.

Eberhart, S.A., and W.A. Russell. 1966. Stability parameters for comparing varieties. Crop Sci. 6:36-40. doi:10.2135/cropsci1 966.0011183X000600010011x

FAO. 2009. FAOSTAT database. Available at http://faostat.fao. org/site/567/default.aspx\#ancor (verified 8 Sept. 2011). FAO, Rome, Italy.

Frankel, E.N. 1991. Recent advances in lipid oxidation. J. Sci. Food Agric. 54:495-511. doi:10.1002/jsfa.2740540402

Fraser, G.E., D. Sumbureru, P. Pribis, R.L. Neil, and M.A. Frankson. 1997. Association among health habits, risk factors and all-cause mortality in a black California population. Epidemiology 8:168-174. doi:10.1097/00001648-199703000-00008

Gorbet, D.W., and D.A. Knauft. 1997. Registration of 'SunOleic 95R' peanut. Crop Sci. 37:1392. doi:10.2135/cropsci1997.001 1183X003700040081x

Grande, S.M., and M. Denke. 1990. Dietary influences on serum lipids and lipoproteins. J. Lipid Res. 31:1149-1172.

Groff, J.L., S.S. Gropper, and S.M. Hunt. 1996. Lipid. p. 113-146. In Advanced nutrition and human metabolism. West Publishing, Minneapolis/St. Paul, MN.

Hammonds, E.G., D. Duvick, D. Wang, D.H. Dodo, and R.N. Pittman. 1997. Survey of the fatty acid composition of peanut (Arachis hypogaea L.) germplasm and characterization of their epoxy and eicosenoin acids. J. Am. Oil Chem. Soc. 74:12351239. doi:10.1007/s11746-997-0050-z

Holaday, P.E., and J.L. Pearson. 1974. Effects of genotype and production area on the fatty acid composition, total oil and protein in peanuts. J. Food Sci. 39:1206-1209. doi:10.1111/j.1365-2621.1974.tb07355.x 
Hotelling, H. 1933. Analysis of a complex of statistical variables into principal components. J. Educ. Psychol. 24:417-441. doi:10.1037/h0071325

ICRISAT. 2009. ICRISAT archival report 2009. Sustaining biodiversity of sorghum, pearl millet, small millets, groundnut, pigeonpea and chickpea for current and future generations. Available at http://www.icrisat.org/what-we-do/ publications/archival-reports/icrisat-arr-2009.pdf (verified 8 Sept. 2011). ICRISAT, Patancheru, India.

Infrasoft International. 2000. The complete software solution using a single screen for routine analysis, robust calibrations, and networking; Manual, FOSS NIRSystems/TECATOR. Infrasoft International, Silver Spring, MD.

Isleib, T.G., J.C. Wynne, and S.N. Nigam. 1994. Groundnut breeding. p. 552-623. In J. Smartt (ed.) The groundnut crop - A scientific basis for improvement. Chapman \& Hall, London, UK.

Jiang, H.F., X.P. Ren, S.Y. Wang; X.J. Zhang, J.Q. Huang, L. BoShou, C.C. Holbrook, and H.D. Upadhyaya. 2010. Development and evaluation of peanut germplasm with resistance to Aspergillus flavus from core collection. Acta Agron. Sin. 36:428-434. doi:10.3724/SP.J.1006.2010.00428

Kim, K.S., S.H. Park, M.G. Choung, and Y.S. Jang. 2007. Use of near-infrared spectroscopy for estimating fatty acid composition in intact seeds of rapeseed. J. Crop Sci. Biotech. 10:15-20.

Kris-Etherton, P.M. 2001. The effects of nuts on coronary heart disease risk. Nutr. Rev. 59:103-111. doi:10.1111/j.1753-4887.2001.tb06996.x

Kusuma, V.P., G. Yugandhar, B.C. Ajay, M.C.V. Gowda, and H.D. Upadhyaya. 2007. Identification of sources of multiple disease resistance in groundnut (Arachis hypogaea L.) mini core. p. 31-32. In Indian Soc. Oilseeds Res. Natl. Seminar Abstr., Hyderabad, India. 29-31 Jan. 2007. Directorate of Oilseeds Research, Rajendranagar, Hyderabad, India.

Lands, W.E.M. 1997. The two faces of essential amino acids. Inform 8:1141-1147.

Misra, J.B., R.S. Mathur, and D.M. Bhatt. 2000. Near-infrared transmittance spectroscopy: A potential tool for nondestructive determination of oil content in groundnuts. J. Sci. Food Agric. 80:237-240. doi:10.1002/(SICI)10970010(20000115)80:23.0.CO;2-9

Mozingo, R.W., S.F. O’Keefe, T.H. Sanders, and K.W. Hendrix. 2004. Improving shelf life of roasted and salted inshell peanuts using high oleic fatty acid chemistry. Peanut Sci. 31:40-45. doi:10.3146/pnut.31.1.0009

Nigam, S.N., S.L. Dwivedi, Y.L.C. Rao, and R.W. Gibbons. 1990. Registration of 'ICGV 87128' peanut cultivar. Crop Sci. 30:959. doi:10.2135/cropsci1990.0011183X003000040049x
Nigam, S.N., S.L. Dwivedi, Y.L.C. Rao, and R.W. Gibbons. 1991 Registration of 'ICGV 87141' peanut. Crop Sci. 31:1096. doi:10.2135/cropsci1991.0011183X003100040072x

Norden, A.J., D.W. Gorbet, D.A. Knauft, and C. Young. 1987. Variability for oil quality among peanut genotypes in the Florida breeding programme. Peanut Sci. 14:7-11. doi:10.3146/ i0095-3679-14-1-3

O’Bryne, D.J., D.A. Knauft, and R.B. Shireman. 1997. Lowfat monounsaturated rich diets containing high-oleic peanuts improve serum lipoprotein profiles. Lipids 32:687-695. doi:10.1007/s11745-997-0088-y

Panford, J.A. 1990. Determination of oil content of seeds by NIR: Influence of fatty acid composition on wave length selection. J. Am. Oil Chem. Soc. 67:1627-1634. doi:10.1007/BF02540751

Patterson, H.D., and R. Thompson. 1971. Recovery of interblock information when block sizes are unequal. Biometriks 58:545-554. doi:10.1093/biomet/58.3.545

Reddy, P.S. 1988. Genetics, breeding and varieties. p. 200-317. In P.S. Reddy (ed.) Groundnut. Publication and Information Division, Indian Council of Agricultural Research, New Delhi, India.

Srivastava, N. 2010. Identification of contrasting parental material for salinity tolerance based on morphological, physiological, and biochemical study and molecular diversity by SSR molecular markers in groundnut (Arachis hypogaea). Ph.D. thesis. Jawaharlal Nehru Technological University, Hyderabad, India.

Tillman, B.L., D.W. Gorbet, and G. Person. 2006. Predicting oleic and linoleic acid content of single peanut seeds using nearinfrared reflectance spectroscopy. Crop Sci. 46:2121-2126. doi:10.2135/cropsci2006.01.0031

Upadhyaya, H.D. 2005. Variability for drought resistance related traits in mini core collection of peanut. Crop Sci. 45:14321440. doi:10.2135/cropsci2004.0389

Upadhyaya, H.D., P.J. Bramel, R. Ortiz, and S. Singh. 2002. Developing a mini core of peanut for utilization of genetic resources. Crop Sci. 42:2150-2156. doi:10.2135/cropsci2002.2150

Upadhyaya, H.D., R. Ortiz, P.J. Bramel, and S. Singh. 2003. Development of groundnut core collection using taxonomical, geographical and morphological descriptors. Genet. Resour. Crop Evol. 50:139-148. doi:10.1023/A:1022945715628

VSN International. 2010. GenStat software for windows. Release 13.1. VSN International Ltd., Hemel Hempstead, UK.

Wald, A. 1943. Test of statistical hypothesis concerning several parameters when the number of observations is large. Trans. Am. Math. Soc. 54:426-482. doi:10.1090/S0002-9947-1943-0012401-3

Ward, J. 1963. Hierarchical grouping to optimize an objective function. J. Am. Stat. Assoc. 38:236-244. doi:10.2307/2282967 